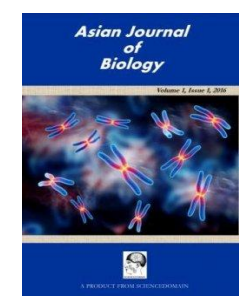

\title{
Occurrence of Cassava Mosaic Disease Related to Agro-ecosystem in Farmer's Fields located in Kongo Central Province, Democratic Republic of Congo
}

\author{
M. Muengula-Manyi ${ }^{1,2,3^{*}}$, A. Ngombo ${ }^{2}$, A. Kalonji ${ }^{1}$, P. Tshiendesha-Musokandu ${ }^{4}$, \\ S. Dekwize-Diakabi ${ }^{5}$, R. Kayembe ${ }^{1}$, N. Kalonji ${ }^{1}$, D. Dianda ${ }^{3}$, J. G. Kasongo, \\ E. Tshibangu ${ }^{3}$, P. Tshilenge-Djim ${ }^{1,2}$ and A. Kalonji-Mbuyi ${ }^{1,2,6}$ \\ ${ }^{1}$ Phytopathology Unit, Faculty of Agronomy, University of Kinshasa, P.O.Box 117, Kinshasa XI, \\ Democratic Republic of Congo. \\ ${ }^{2}$ Department of Crop Production, Faculty of Agronomy, University of Kinshasa, P.O.Box 117, Kinshasa \\ XI, Democratic Republic of Congo. \\ ${ }^{3}$ Faculty of Agronomy, Protestant University in the Heart of Congo, P.O.Box 856, Mbuji-Mayi, \\ Democratic Republic of Congo. \\ ${ }^{4}$ Higher Institute of Agronomic Studies of Kamponde, P.O.Box 187, Kananga, Kasai Central Province, \\ Democratic Republic of Congo. \\ ${ }^{5}$ Higher Institute of Rural Development of Lwiza, Kasai Central Province, \\ Democratic Republic of Congo. \\ ${ }^{6}$ Regional Nuclear Energy Center of Kinshasa (CREN-K), P.O.Box 868, Kinshasa XI, \\ Democratic Republic of Congo.
}

Authors' contributions

This work was carried out in collaboration between all authors. Author MMM formulated the survey questions, wrote the protocol and monitored the field survey. Authors AN, AK, RK and NK carried out the epidemiological surveys in farmers' fields and wrote the first draft of manuscript. Authors DD, JGK, ET, PTM and SDD complete data analysis and literature review. Authors PTD and AKM wrote the final manuscript. All authors read and approved the final manuscript.

Article Information

DOI: $10.9734 / \mathrm{AJOB} / 2017 / 34302$ Editor(s):

(1) Xing Li, Division of Biomedical Statistics and Informatics, Department of Health Sciences Research, Mayo Clinic College of Medicine, USA. Reviewers:

(1) Zinga Innocent, University of Bangui, Central African Republic. (2) Andrew Sarkodie Appiah, Biotechnology and Nuclear Agriculture Research Institute, Ghana. Complete Peer review History: http://www.sciencedomain.org/review-history/20033 


\section{ABSTRACT}

Aim: To assess the Cassava Mosaic Disease (CMD) pressure by analyzing its incidence, severity and gravity, and to characterize agro-ecosystems where cassava farmers' fields are established.

Place and Duration: The study was conducted in three different localities (Mvuazi, Ndembo and Pompage) in Kongo Central province, Democratic Republic of Congo, from June to December 2016. Methodology: One hundred and fifty farmers' fields randomly selected were investigated during epidemiological survey, with 50 fields in each locality. In each field selected, 30 cassava plants randomly selected in a square of $10 \mathrm{~m} \times 10 \mathrm{~m}$ were analyzed. The CMD incidence, severity and gravity were collected, and agronomic and environmental factors relative to cassava fields were analyzed.

Results: In general, CMD was observed in the three localities, with pressure depending upon to localities and fields. The distance between two neighboring fields could vary from 5 to 35 or even $50 \mathrm{~m}$. Pathological parameters show significant difference $(P=.05)$ among fields for the same locality. The lowest pressure was recorded in Mvuazi locality (with 12.8\% for incidence, score 2 for severity, and $15 \%$ for gravity), while the highest pressure was recorded in Pompage (with $20 \%$ for incidence, score 3 for severity, and $32 \%$ for gravity). Data recorded on agro-environmental factors show that farmers of the three localities used almost the same agricultural practices. Analysis of data reported suggest that the origin and the type of cassava material cuttings used can play a principal role in the propagation and development of CMD in most of cassava cultivation regions.

Conclusion: The results of the present study revealed that CMD was present in different localities surveyed, and its pressure varies among localities, and from one field to another for the same locality. Agricultural practices used by farmers can play an important role in the propagation of CMD in different regions of cassava cultivation.

Keywords: Cassava mosaic disease; farmers' fields; agro-ecosystem; Kongo Central province; DRCongo.

\section{INTRODUCTION}

Cassava (Manihot esculenta Crantz) is an important source of calories for thousands of people living in sub-Saharan Africa [1,2]. Plant with high potential and adapting to different environments [3], cassava is however subject to the attacks of Cassava Mosaic Disease (CMD) which constitutes a serious and persistent threat to the food security of populations mainly living of that food.

In Africa, various works of selection and improvement of cassava led to the development of varieties containing acceptable agronomic and qualitative characteristics, and resistant to diseases such as CMD and Cassava Bacterial Blight (CBB) $[4,5]$. These varieties have often been introduced and distributed in many regions to control the CMD pandemic. Despite these breeding, improvement and extension efforts, it was observed that the CMD continues to spread with high incidence and severity levels. One of causes that would be the basis for the CMD perpetuation in these regions is the low adoption of improved varieties by farmers. Indeed, farmers felt that these varieties did not meet their expectations and preferences [6,7], which results in the widespread use of local varieties.
In the Democratic Republic of Congo (DRC), studies conducted on the evaluation of the CMD pressure indicate that the cassava germplasm is susceptible to this viral disease. For examples, in Yangambi region (Eastern province), Monde [8] found that the majority of local varieties showed severe symptoms of the disease, compared with improved varieties. In Bukavu region (Sud Kivu province), Bisimwa [9] noted that local cassava varieties grown in different agro-ecosystems were all susceptible to various biotic diseases identified on cassava. In Gandajika (Eastern Kasaï province), Muengula-Manyi et al. [10] observed that local varieties grown by farmers are severely attacked by CMD compared to improved varieties.

Various other scientific studies have shown that local cassava varieties are severely attacked than improved varieties. Jeremiah \& Kulembeka [11] mentioned that all local cassava varieties available are susceptible to CMD. In many countries, CMD would have reached a high severity degree on farmers' fields, which may reduce the yield of cassava tuberous roots. The level of CMD infection varying from agroecological systems [12], and poor farming practices and marginal agro-environmental 
conditions observed in farmers' fields are favorable for CMD development.

This study aimed to assess the CMD pressure by analyzing the disease incidence, severity and gravity in Mvuazi, Ndembo and Pompage localities (in the Kongo Central province), and to characterize agro-environmental factors where cassava farmers' fields are established.

\section{MATERIALS AND METHODS}

\subsection{Sites Description and Field Sampling}

Epidemiological surveys were conducted in Mvuazi, Ndembo and Pompage localities (Kongo Central province) in DRC. These regions fall within the Aw4 climate type according to Köppen classification characterized by 4 months of dry season coupled 8 months of rainy season. Daily temperature averages $22-24^{\circ} \mathrm{C}$ and can reach a maximum of $30^{\circ} \mathrm{C}$. The average annual rainfall ranges around $1,522 \mathrm{~mm}$. The surveyed sites were characterized by the presence of savannah dominated by herbaceous species such Hyparrhenia diplandra, Mucuna sp., Panicum maximum and Pennisetum purpureum. In some places, it is observed ragged forest where dominated shrub species such as Lussonia angolensis and Hymenocardia acida. According to Pauwels [13], soils of Kongo Central region are varying types, and revealed the presence of sandy and clay soils.

Epidemiological surveys were conducted in cassava farmers' fields during the period from June to December 2016. In each locality, 50 fields randomly selected were investigated. In each field selected, 30 cassava plants randomly selected in a square of $10 \mathrm{~m} \times 10 \mathrm{~m}$ were analyzed.

\subsection{Variables Studied}

\subsubsection{Pathological variables}

During epidemiological investigations, pathological variables recorded were CMD incidence, severity and gravity. The CMD incidence was assessed by the proportion of diseased plants compared to 30 plants analyzed. CMD severity symptom was assessed using a scale ranging from 1 to 5 described by Hahn et al. [14], where 1 represents an asymptomatic cassava plant (apparently healthy) and 5 a severely infected cassava plant with reduction of leaflets. The CMD gravity was assessed in each diseased plant by the proportion of leaves with typical symptoms of the disease.

\subsubsection{Agronomic and environmental factors}

For each field surveyed, agronomic and environmental characteristics as described by Muengula-Manyi et al. [10] were determined. They include field location, origin and type of cassava material used, age of fields, topography of land, the practice of intercropping, type of crops mixed with cassava, and the topping practice.

\subsection{Data Analysis}

Statistical analysis of data recorded was made possible through the $\mathrm{R}$ software and Statistix 8.0 (free version). The recorded data were submitted to analysis of variance followed by multiple comparisons by Tukey's HSD, to determine significant differences $(P=.05)$ between the surveyed sites. CMD incidence and gravity were previously submitted to a logarithmic transformation to base 10 (log10). The comparison of means was made using the least significant difference test (LSD) at the $5 \%$ probability.

\section{RESULTS}

\subsection{Incidence, Severity and Gravity of Cassava Mosaic Disease}

Results obtained on CMD incidence, severity and gravity recorded in the 3 localities are reported in Table 1.

Table 1. Incidence, severity and gravity of CMD recorded in Mvuazi, Ndembo and Pompage locality

\begin{tabular}{llll}
\hline Locality & \multicolumn{3}{c}{ Pathological variables recorded } \\
\cline { 2 - 4 } & $\begin{array}{l}\text { Incidence } \\
\text { (\%) }\end{array}$ & $\begin{array}{l}\text { Severity } \\
\text { (scale 1 - 5) }\end{array}$ & $\begin{array}{l}\text { Gravity } \\
\mathbf{( \% )}\end{array}$ \\
\hline Mvuazi & $12.8^{\mathrm{b}}$ & 2 & $15^{\mathrm{c}}$ \\
Ndembo & $15.2^{\mathrm{b}}$ & 3 & $25^{\mathrm{b}}$ \\
Pompage & $20^{\mathrm{a}}$ & 3 & $32^{\mathrm{a}}$ \\
\hline In the same column, means followed by the same letter \\
are not significantly different at 5\% of probability
\end{tabular}

In general, CMD was present in all sites surveyed with levels of incidence, severity and gravity varying between localities, and from one field to another in the same locality. There were significant differences for disease incidence and 
gravity among fields for the three sites (Table 1). Overall, the mean incidence for all fields surveyed was $16 \%$, severity score was 2.6 , and gravity equal to $24 \%$. Details for each locality revealed that the incidence of CMD was $12.8 \%$ in Mvuazi, $15.2 \%$ in Ndembo and $20 \%$ in Pompage. The mean of CMD severity was equal to 2 in Mvuazi, and 3 in Ndembo and Pompage, and the gravity was respectively equal to 15,25 and $32 \%$.

\subsection{Agronomic and Environmental Characteristics of Fields Investigated}

The results of different agronomic and environmental factors analyzed for each cassava field prospected in Mvuazi, Kimpese and Pompage localities are reported in Table 2.

Table 2. Frequency (\%) of cassava fields characteristics in 3 localities investigated in Kongo Central region

\begin{tabular}{|c|c|c|c|}
\hline \multirow{2}{*}{$\begin{array}{l}\text { Characteristics } \\
\text { of fields }\end{array}$} & \multicolumn{3}{|c|}{ Localities } \\
\hline & Mvuazi & Ndembo & Pompage \\
\hline \multicolumn{4}{|l|}{ Field location } \\
\hline Secondary forest & 40 & 70 & 64 \\
\hline Savannah & 60 & 30 & 36 \\
\hline \multicolumn{4}{|l|}{ Site topography } \\
\hline Flat land & 70 & 24 & 60 \\
\hline Land with slope & 30 & 76 & 40 \\
\hline \multicolumn{4}{|c|}{ Origin of cassava material used } \\
\hline Research center & 90 & - & - \\
\hline Old field & 10 & 100 & 100 \\
\hline \multicolumn{4}{|c|}{ Type of cassava material used } \\
\hline Local & 14 & 90 & 96 \\
\hline \multicolumn{4}{|l|}{ Age of field } \\
\hline 1 to 6 months & 8 & 10 & 8 \\
\hline 7 to 12 months & 86 & 70 & 72 \\
\hline $\begin{array}{l}\text { Older than } 12 \\
\text { months }\end{array}$ & 6 & 20 & 20 \\
\hline \multicolumn{4}{|c|}{ Intercropping practice } \\
\hline Yes & 15 & 90 & 85 \\
\hline No & 85 & 10 & 15 \\
\hline \multicolumn{4}{|c|}{ Crop mixed with cassava } \\
\hline Legume & 15 & 35 & 45 \\
\hline Cereal & 75 & 25 & 25 \\
\hline Vegetable crop & 10 & 40 & 30 \\
\hline \multicolumn{4}{|c|}{ Topping practice } \\
\hline Yes & 66 & 68 & 70 \\
\hline No & 34 & 32 & 30 \\
\hline
\end{tabular}

\subsubsection{Field location and site topography}

Cassava fields investigated were established either in secondary forest or savannah. In the 3 localities, cassava crop grown in secondary forest represented $58 \%$, while those established in savannah represented $42 \%$. Famers' fields were established either on flat land or on land with slope. It was observed that $51.3 \%$ of cassava crops were grown on flat lands and $48.6 \%$ on lands with slope. Details of cassava fields location and site topography for each locality are described in Table 2.

\subsubsection{Origin and type of cassava material used}

Analysis of data reported in Table 2 revealed that $30 \%$ of farmers used cassava cuttings obtained from a Research Center, and $70 \%$ used cuttings obtained from their previous fields. Farmers used local or genetically improved cassava varieties. Local cassava varieties were grown in $66.6 \%$ of fields, while improved varieties were planted in $33.3 \%$ of fields.

\subsubsection{Age of field}

According on the date of cassava plantation, fields investigated were classified in 3 groups. The first group included 1 to 6 months old cassava field, the second group with 7 to 12 months, and the third group with fields older than 12 months (Table 2). Results obtained revealed that $8.6 \%$ of cassava fields were 1 to 6 months old, $76 \%$ were 7 to 12 months old, and $15.3 \%$ were older than 12 months. Details of the three groups for each locality are described in Table 2.

\subsubsection{Intercropping practice and type of crops mixed with cassava}

The results of this study revealed that cassava was generally grown in association with other crops such as legumes, cereal or vegetable crops. Analysis of these results indicated that $63.3 \%$ of cassava were mixed with other crops, while in $36.6 \%$ of cases, cassava crop was grown alone. In general, $31.6 \%$ of cassava stands were grown in association with legumes (soybeans or beans), $41.6 \%$ with cereal (principally maize) and $26.6 \%$ with vegetable crops (sweet potatoes). Frequency of intercropping practice and crops mixed with cassava varied according to localities surveyed (Table 2).

\subsubsection{Topping practice}

It observed that field topping was generally practiced in the three localities surveyed. This 
suggest that cassava leaves are appreciated such an edible legume to meet household needs. Field topping was practiced in $68 \%$ of cassava stands, while no topping was reported in $32 \%$ of fields investigated.

\section{DISCUSSION}

This study revealed the presence of cassava mosaic disease (CMD) in different cassava farmers' fields located in Mvuazi, Ndembo and Pompage localities in Kongo Central province. Overall, CMD pressure assessed by the analysis of incidence, severity and gravity generally varies among localities, and from one field to another in the same locality.

The analysis of pathological variables reported in Table 1 revealed significant difference $(P=.05)$ among localities. In general the CMD pressure was low in Mvuazi, whereas it was higher in Pompage locality. Results of this study show that CMD pressure is slightly lower compared to data presented in previous studies. In other regions of DRC, Sseruwagi et al. [15] revealed that the mean incidence of CMD during the period 20022003 was approximately $60 \%$, with severity score equal to 3.1. According to Ariyo et al. [16] and Ntawuruhunga et al. [17], usually the incidence and severity of CMD vary according to the year, and from one region to another. Adjata et al. [18] mentioned that the level of CMD incidence probably changes with the pressure of inoculum, which varies from one site to another. Based on our findings and those of previous studies, it is clear that pathological parameters (incidence, severity and gravity) fluctuate depending on several factors such as agronomic, environmental and the pressure of inoculum prevailing in a region, as well as time or period of observations. In addition, Sseruwagi et al. [15] mentioned that in some moderately resistant varieties, symptoms of CMD can be localized or absent in some parts of cassava plant. Muengula-Manyi et al. $[10,19]$ also observed on a diseased cassava plant that CMD symptoms did not necessarily appeared on all leaves present on the plant. These observations explain the variability of level of gravity recorded on the diseased plants surveyed.

Results reported in Table 2 indicate in general that farmers use almost the same agricultural practices in the cultivation of cassava. Based on characteristics of fields surveyed, it appeared that $90 \%$ of farmers located in Mvuazi use cuttings obtained from the Research center, while all farmers (100\%) founded in Ndembo and Pompage localities use cuttings from their previous fields. In addition, in Mvuazi locality, $86 \%$ of cassava varieties planted are genetically improved, while $93 \%$ of cassava material used in Ndembo and Pompage localities are local varieties (Table 2). These observations may explain the low CMD pressure noted in Mvuazi compared to the two others localities. The results of this study corroborate findings reported by Bisimwa [9] who observed in Bukavu region, that cassava farmers' fields heavily attacked by biotic diseases were planted from local varieties. According to Hillocks \& Thresh [20], in some regions the lack of improved varieties orient farmers towards large-scale use of local varieties; and the high frequency of use of local varieties could also be explained by the quest characteristics valued by farmers and by the cost of improved cassava varieties cuttings. In addition, the use of cuttings without health guarantee, taken from previous fields may explain the permanent presence of CMD in some cassava production regions.

Although the CMD was observed in the three localities, its incidence was overall lower compared to data reported by Sseruwagi et al. [15], while the severity score reported in these two studies was similar. The low level of CMD incidence reported in this study may be due to the use of intercropping practice and the type of crop mixed with cassava. Indeed, there was different crops intercropped with cassava in the three localities surveyed. For example, in Mvuazi, cassava was mixed with cereal in $75 \%$ of fields investigated, while in Ndembo it was mixed with vegetable crop in $40 \%$, and in Pompage with legumes in $45 \%$ (Table 2). Our results corroborate observations made by Monde [8] who observed in the Yangambi region, that incidence and severity of CMD were very lower in fields where cassava was mixed with beans compared to fields where cassava was cultivated without crop mixed.

\section{CONCLUSION}

The results of the present study revealed that CMD occurs in the three localities surveyed, and its level pressure varies between localities, and between different fields in the same locality. In general, results obtained showed that farmers used almost the same agricultural practices to establish their cassava fields. Origin and type of cassava material used indeed play a significant role in the spread and development of CMD. In 
the region where improved varieties were used, CMD pressure was lower than where local varieties were used. The low level of incidence, severity and gravity of CMD can be attributed to the use of intercropping practice and the type of crop mixed with cassava.

\section{ACKNOWLEDGMENT}

This study was financially supported by Acaédmie de Recherche et d'Enseignement Supérieur (ARES) - Belgique through the Programme Ad Hoc of ARES-UNIKIN. The principal author thanks the authorities of ARES for funding his research project.

\section{COMPETING INTERESTS}

Authors have declared that no competing interests exist.

\section{REFERENCES}

1. Alabi OJ, Ogbe FO, Bandyopadhyay R, Lava Kumar P, Dixon AGO, Hughes Jd'A, Naidu RA. Alternate hosts of African cassava mosaic virus and East African cassava mosaic Cameroon virus in Nigeria. Arch. Virol. 2008;153:1743-1747.

2. FAOSTAT. FAO database. Food and agriculture organization of the United Nations, Rome, Italy; 2009. Available:http//FAOSTAT.fao.org/site/339/d efault.aspx

3. Kawano K, Daza P, Aruya A, Rios M, Gonzales WMF. Evaluation of cassava germplasm for productivity. Crop Sci. 1978; 18:372-380.

4. Cach NT, Pérez JC, Lenis JI, Calle F, Morante F, Ceballos H. Epistasis in the expression of relevant traits in cassava (Manihot esculenta Crantz) for sub-humid conditions. J. of Heredity. 2005;96:586592.

5. Pérez JC, Ceballos $H$, Jaramillo $G$, Morante N, Calle F, Arias B, Bellotti AC. Epistasis in cassava (Manihot esculenta Crantz) adapted to mild-altitude valley environment. Crop Sci. 2005;45:14911496.

6. Nweke FI. Farm level practices relevant to cassava plant protection. Afr. Crop Sc. J. 1994;2:563-582.

7. Benesi IRM. Characterization of Malawian cassava germ plasm for diversity, starch extraction and its native and modified properties. PhD Thesis. Department of plant sciences: Plant breeding, faculty of natural and agriculture sciences, university of the free state, South Africa; 2005.

8. Monde G. Epidémiologie diversité génétique et phylogéographie des virus de la mosaïque africaine du manioc dans la région de Yangambi en République Démocratique du Congo. Thèse de doctorat, Université catholique de Louvain, Louvain-la-Neuve, Belgique; 2010.

9. Bisimwa E. Epidémiologie diversité génétique, distribution et contrôle des virus de la mosaïque africaine du manioc et de son vecteur (Bemisia tabaci) dans la région du Sud-Kivu en République Démocratique du Congo. Thèse de doctorat, Université catholique de Louvain, Louvain-la-Neuve, Belgique; 2011. French.

10. Muengula-Manyi M, Nkongolo KK, Bragard C, Tshilenge-Djim P, Winter S, KalonjiMbuyi A. Incidence, severity and gravity of cassava mosaic disease in savannah agro-ecological region of DR-Congo: Analysis of agro-environmental factors. Am. J. of Plant Sci. 2012;3:512-519.

11. Jeremiah SC, Kulembeka HP. Screening of local cassava varieties against cassava mosaic disease and cassava green mite. In: Proceedings of the $13^{\text {th }}$ ISTRC Symposium, Arusha, Tanzania; 2007.

12. Balyejusa KE, Bua A, Fregene M, Egwang $T$, Gullberg U, Westerbergh A. The effect of cassava mosaic disease on the genetic diversity of cassava in Uganda. Euphytica. 2005;146:45-54.

13. Pauwels L. Catalogue des plantes cultivées au Jardin Botanique de Kisantu; 1977.

14. Hahn SK, Terry ER, Leuschner ER. Breeding cassava for resistance to cassava mosaic disease. Euphytica. 1980; 29:673-683.

15. Sseruwagi $P$, Sserubombwe WS, Legg JP, Ndunguru J, Thresh JM. Methods of surveying the incidence and severity of cassava mosaic disease and whitefly vector populations on cassava in Africa: A review. Virus Research. 2004;100:129142.

16. Ariyo AO, Dixon AGO, Atiri GI. Whitefly Bemisia tabaci (Homoptera: Aleyrodidae) infestation on cassava genotypes grown at different Ecozones in Nigeria. J. of Econ. Entom. 2005;98:611-617. 
17. Ntawuruhunga $P$, Okao-Okuja G, Bembe A, Obambi M, Mvila AJC, Legg JP. Incidence and severity of cassava mosaic disease in Republic of Congo. Afr. Crop Sc. J. 2007; 15(1):1-9.

18. Adjata KD, Muller $E$, Peterschmitt $M$, Aziadekey M, Gumedzoe YMD. Incidence of cassava viral diseases and first identification of East cassava mosaic virus and Indian cassava mosaic virus by PCR in cassava (Manihot esculenta Crantz) fields in Togo. Am. J. of Plant Physiol. 2008;3:73-80.
19. Muengula-Manyi M, Mukwa L, Nkongolo KK, Tshilenge-Djim P, Winter S, Bragard C, Kalonji-Mbuyi A. Assessing reactions of genetically improved and local cassava varieties to cassava mosaic disease (CMD) infection in a savannah region of the DR-Congo. Am. J. of Plant Sci. 2013; 4:824-837.

20. Hillocks RJ, Thresh JM. Cassava mosaic and cassava brown streak virus diseases in Africa: A comparative guide to symptoms and etiologies. Roots. 2000;7(1):1-8.

(C) 2017 Muengula-Manyi et al.; This is an Open Access article distributed under the terms of the Creative Commons Attribution License (http://creativecommons.org/licenses/by/4.0), which permits unrestricted use, distribution, and reproduction in any medium, provided the original work is properly cited.

\section{Peer-review history:}

The peer review history for this paper can be accessed here: http://sciencedomain.org/review-history/20033 